\title{
West Virginia Dentists' Perception of the Knowledge and Skills of Two vs. Four Year Dental Hygiene Graduates
}

\author{
Kaitlyn M. McQuain \\ kmcory@mix.wvu.edu
}

Follow this and additional works at: https://researchrepository.wvu.edu/etd

Part of the Dental Hygiene Commons

\section{Recommended Citation}

McQuain, Kaitlyn M., "West Virginia Dentists' Perception of the Knowledge and Skills of Two vs. Four Year Dental Hygiene Graduates" (2020). Graduate Theses, Dissertations, and Problem Reports. 7751.

https://researchrepository.wvu.edu/etd/7751

This Thesis is protected by copyright and/or related rights. It has been brought to you by the The Research Repository @ WVU with permission from the rights-holder(s). You are free to use this Thesis in any way that is permitted by the copyright and related rights legislation that applies to your use. For other uses you must obtain permission from the rights-holder(s) directly, unless additional rights are indicated by a Creative Commons license in the record and/ or on the work itself. This Thesis has been accepted for inclusion in WVU Graduate Theses, Dissertations, and Problem Reports collection by an authorized administrator of The Research Repository @ WVU. For more information, please contact researchrepository@mail.wvu.edu. 
West Virginia Dentists' Perception of the Knowledge and Skills of Two vs. Four Year Dental

Hygiene Graduates

Kaitlyn McQuain

Thesis Submitted

to the School of Dentistry

at West Virginia University

in partial fulfillment of the requirements for the degree of

Masters of Science In Dental Hygiene

Alcinda K. Trickett Shockey, DHSc, MA, BSDH, RDH, CHS-IV, CTTS, CNTA, Chair

R. Constance Wiener, DMD, PhD

Ashlee B. Sowards RDH, BSDH, MSDH, NCTTP

Department of Dental Hygiene

Morgantown, West Virginia

2020

Keywords: Hygienist, Four-year, Perceptions, Knowledge, Skills, Two-year, Dental, Hygiene, Graduates, West Virginia 


\author{
ABSTRACT \\ West Virginia Dentists' Perception of the Knowledge and Skills of Two vs. Four Year Dental \\ Hygiene Graduates \\ Kaitlyn McQuain
}

The entry level for the dental hygiene profession has, historically been an associate degree. In 2016 the American Dental Hygiene Association (ADHA) approved the Bachelor's Degree level of education as the preferred for entry level degree. This study is to determine practicing West Virginia dentists preference for the education level of their entry-level dental hygiene employees. There were 1020 surveys electronically distributed to practicing WV dentists to obtain their opinions and preferences. WVU Research Electronic Data Capture (REDCap) was used to determine response percentages and Chi-square statistics were used to compare 2017 to 2019 response rates. Between 2016-2017 and 2018-2019, there was a statistical significant difference in dentist's preference to hire 4-year over 2-year graduates (Chi Square, 5.090, $P=.032$ ); however additional pay or the perception of greater knowledge relating to 4-year graduates vs. 2-year graduates failed to reach significance (Chi Square, 0.174; $P=.750$; Chi Square, 0.368; $P=.601$, respectively). Dentists in West Virginia do not prefer 4-year vs. 2-year dental hygiene graduates for entry level positions; however, comparing 2016-2017, and 20182019, there was a trend for greater preference to hire 4-year vs. 2-year graduates. Proven by this study, there is not financial gain from obtaining the higher degree. For aspiring dental hygiene students who wish to go into other aspects of dental hygiene such as corporate, research and government sectors, a 4-year degree would be the ideal academic path. 
TABLE OF CONTENTS

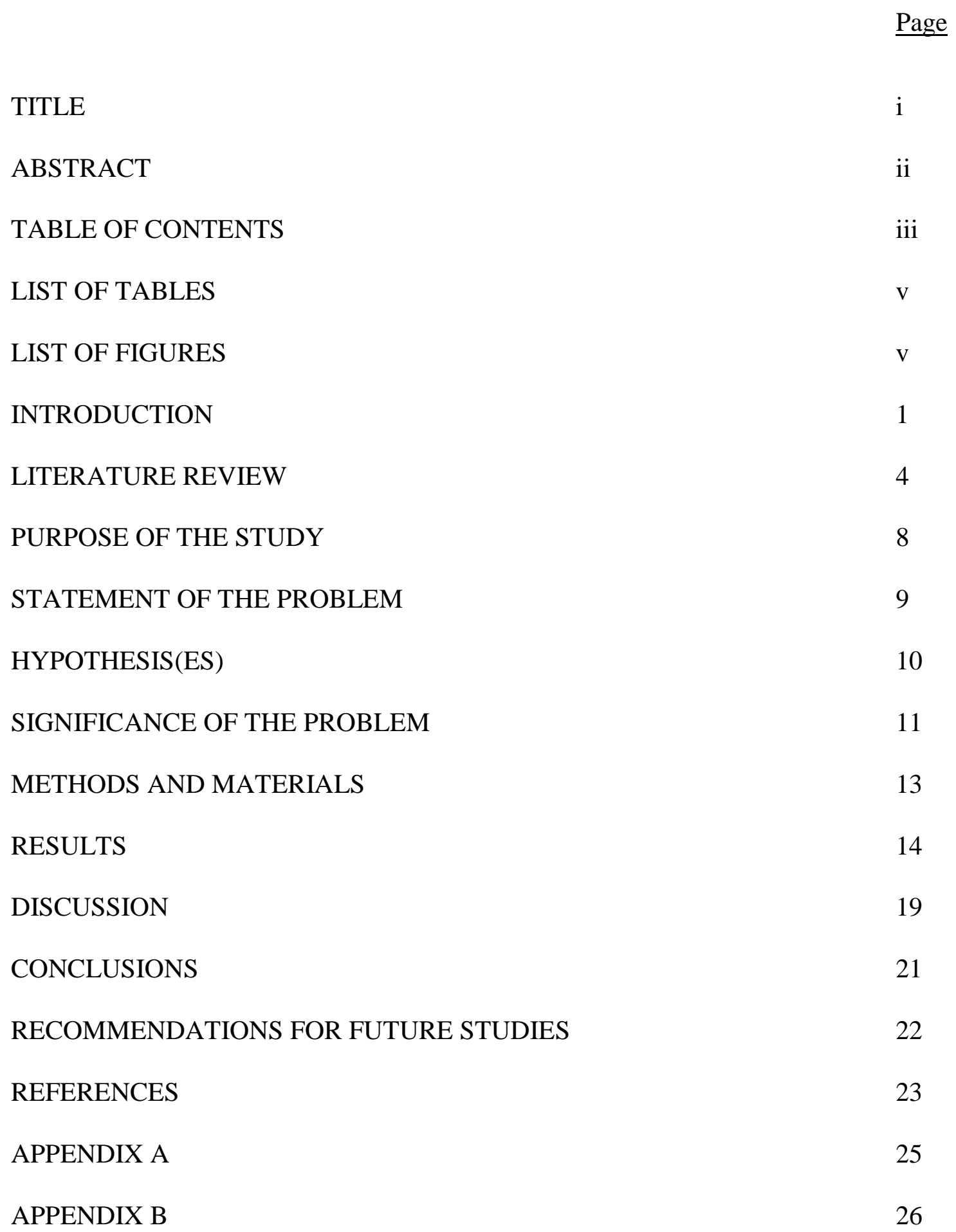


TABLE OF CONTENTS CONTINUED

$\underline{\text { Page }}$

$\begin{array}{ll}\text { APPENDIX C } & 27\end{array}$

$\begin{array}{ll}\text { APPENDIX D } & 28\end{array}$

$\begin{array}{ll}\text { APPENDIX E } & 29\end{array}$

$\begin{array}{ll}\text { APPENDIX F } & 31\end{array}$

VITA 33

$\begin{array}{ll}\text { Dedications } & 36\end{array}$ 


\section{LIST OF TABLES}

$\underline{\text { Page }}$

Table 1: Sample Characteristics

Table 2: Survey statements and Responses

Table 3: Survey statements and Responses

Table 4: Bivariate analysis by year of survey 


\section{INTRODUCTION}

Students aspiring to be dental hygienists currently have the option of choosing between a two-year degree and a four-year degree when deciding their individual path for education. When reviewing the two options, it is common for individuals to think that each route is the same as the result of becoming a Registered Dental Hygienist $(\mathrm{RDH})$ is the goal of both programs. From the general public's perspective, both degrees are equal. Although one option takes more time the two paths have vast differences. When a student is considering the two types of degrees, he or she may have a question such as "Which type of a degree would employers prefer?" and "Which degree holds a higher value, if any?" There is limited literature devoted to which degree dentists find more valuable for their entry-level dental hygienists, and if they believe there to be differences in the characteristics of one degree versus the other.

The American Dental Hygienists' Association (ADHA) supports ta bachelor's degree instead of an associate's degree. The ADHA has further expanded the dental hygiene profession by creating the Advanced Dental Hygiene Practitioner which is a Master's degree level to provide access to care for underserved populations. As an aspiring dental hygiene student, it is important to understand the potentials for advancement when considering the availability of careers pertaining to the different degrees.

Economic considerations are very important for potential dental hygienists to consider when comparing the two different routes of education that can be obtained. Prospective students need to be aware of a greater financial burden when acquiring the higher degree. Some circumstances would preclude a student from becoming a dental hygienist if not for the Associate's level possibility. 
However, the acquisition of a Bachelor's degree has become the preferred entry level for the profession. Potential students should understand the importance of versatility and future job possibilities of having a Bachelor's degree versus an Associate degree. There are many advantages to receiving earning a bachelor's degree. Career advancement opportunities include those in academia, corporate settings and government sectors.

There are many financial similarities in terms of salaries between the two degrees. In clinical hygiene employment opportunities, both degrees can have the same hourly wages, job security, mobility, and job benefits. The student must determine the different advantages and disadvantages between an associate and bachelor degree.

Changing attitudes.

Many employers outside of dentistry are requiring a college degree for employment within their company. The college level education requirement is even for jobs that do not warrant the need for such a level of expertise. This could eventually become a driving factor for employment in a dental setting.

There are intrinsic benefits of a college degree. Individuals who have attended college are provided opportunities to interact with people from different cultures, with varying points of view and interests. The college experience allows for the development of long-lasting friendships, connections, and exposure too many ideas. Attending college improves an individual's writing and communication skills and encourages intellectual growth. College graduates as a whole report that they have greater happiness, happier children, better health such as exercising and less smoking (1). When a student is considering which of the two degrees to pursue, he or she should consider non-financial as well as financial benefits 
In this study, practicing dentists in orthodontics, periodontics, general dentistry and pediatrics gave their perception on if there were a difference in clinical skills, basic science knowledge, and dental knowledge between recent graduates of 4-year and 2-year dental hygiene program. Practicing West Virginia dentists were queried in regards to hiring and salary practices. A comparison of 4-year dental hygiene graduates' clinical, basic science, and professional competency skills and 2-year dental hygiene graduates' clinical, basic science, and professional competency skills was made to determine their preference when making hiring choices within their practices. Another specific aim was to complete a short longitudinal study to determine if there were any changes in dental attitudes and opinions during the adoption of ADHA's recommendation for dental hygiene professional entry-level to be elevated from an Associate degree (2 -year) to a Bachelor degree (4-year) level of education. 


\section{LITERATURE REVIEW}

\section{Basic programs in Dental Hygiene}

There are 328 entry-level accredited dental hygiene programs in the United States and 56 degree completion programs (2). In the state of West Virginia there are 3 entry-level degree programs and 2 degree completion programs. Programs include both Associate and Bachelor degree programs. Degree completion programs are for individuals who hold an Associate's degree but wish to further advance their education to a Bachelor degree. Twenty-seven of the degree completion programs are completely online and 17 offer a hybrid program (3). Such degree completion programs do not have an accrediting agency whereas the entry-level degree is accredited by the American Dental Association.

The American Dental Hygienists' Association leaders are focusing the profession on: research, education, practice, and technology, licensure and regulation, public health, and government. One of the goals is to require a Bachelor's degree as an entry-level degree (eliminate the Associate Degree as an option or require a dental hygienist with an Associate Degree to earn a Bachelor Degree).

In a study of 57 programs to identify information related to the dental hygiene bachelor degree completion programs, it was determined that the curriculum should include a research course, as well as critical thinking assignments, and the development of leadership skills. They indicated that dental hygienists with advanced higher education such as a bachelor's degree and higher would lead to a better-educated workforce and ultimately better patient care (3).

\section{Clinical testing}


Currently, clinical testing is the criteria used to identify qualified dental hygienists. To obtain a license to practice dental hygiene, students must pass one clinical and written exam. Both programs are equivalent in these requirements. Each state has specific requirements as to which clinical exam needs to be taken and passed in order to qualify for licensure. Currently there are five regional clinical board exams (4). Each student takes the National Board Dental Hygiene Examination (NBDHE), the "written" exam, and must have had an effective completion. In order to take these exams the student must have graduated or be enrolled in an accredited dental hygiene program (4).

\section{Perceptions by Dental Hygienists}

New York dental hygienists provided their perceptions about their beliefs about educational needs for the profession. A survey was presented to them to compare the requirements for both associate and baccalaureate degrees. Half of respondents agreed that a Bachelor's degree should be required for entry into the profession; while, nearly half, thought that an associate degree is sufficient for entry into the dental hygiene profession (5). In Canada, a study was conducted to assess the outcomes of dental hygiene degree completion programs. There were only 16 participants, and most reported that Bachelor programs in dental hygiene improved students' self-confidence, knowledge, and critical thinking skills. Researchers for both of these studies concluded that it would be beneficial for the entire profession if the entry- level requirement was the Bachelor level $(5,6,7)$.

\section{Advantages related to attending College, in general}

Individuals who graduate college experience a higher quality of life than individuals who do not attend university. Such individuals often experience a high quality of job conditions, 
career fulfillment and overall are less likely to be unemployed. Graduates are more likely to report that they are in "very good" or "excellent" health, in comparison to those who hold an education less than a high school diploma. Stronger marriages, community connections, stable relationships, are all reported from individuals possessing a bachelor degree (1). Overall, college graduates have a higher quality of life.

\section{Role of dental hygiene in access to care}

A problem for Medicare enrollees is having an adequate number of providers that are willing to participate and if that enrollee has dental coverage $(8,9)$. Advanced programs available to graduates of 4-year programs help to address this access to care need. Medicaid managed care has been implemented for more than 20 years to improve access to good quality care for the Medicaid enrollee. Medicare enrolled individuals often face the poor access and quality of care (8). Although children with Medicaid received care, adult access is limited by the number of dentists willing to accept Medicaid (9).

The American Dental Association's Health Policy Institute researchers determined that a significant number of people needed dental care and were unable to seek treatment due to the lack of participating providers. Many non-elderly adults with low income experienced financial barriers $(8,9,10)$. Dental hygiene can help to fill the gap with access to care issues. Graduates from 4-year programs have opportunities for advanced degrees to address these problems.

\section{The changing roles in the dental hygiene profession}

The Affordable Care Act is providing individuals with more availability and access to care. Also, Individuals are living longer with managed chronic conditions that had limited the lifespan in the past. This is causing new and interesting care patterns that are needed. Dental 
hygienists need to be prepared to expand their professional roles. Dental hygienists need educations which will prepare them to care for diverse people and to prepare them with skills that are flexible, and adaptive. They need to be prepared to be successful and marketable in the profession of dental hygiene $(6,7)$.

Many dental hygienists are advocating for the creation of an accreditation council for education and agreements for Bachelor degree completion programs that are similar to other programs (nursing, etc.) (11). Most dental hygiene professionals believe dental hygiene curriculum must include clinical on-site education and a written and clinical state examination $(2,4,11)$. The ADHA advocates for dental hygiene, and has established its intent to implement the Bachelor's degree as the minimum entry level for dental hygiene practice and to further develop the theoretical base for dental hygiene practice $(12,13)$.

With this knowledge, many prospective dental hygiene students may decide to obtain an Associate's degree, while it is still possible to do so; or may decide that the time is appropriate to complete the Bachelor's degree. 


\section{PURPOSE OF THE STUDY}

Although the ADHA is recommending the Bachelor degree for minimal qualifications, it is unknown if dentist believe this is necessary. The purpose of this study is to determine if there was a difference in West Virginia dentists' opinions between 2016-17 and 2018-19 toward preference in hiring 2-year or 4-year entry level dental hygienists. The ADHA has moved to recommending the bachelor degree for the entry level degree due to the increased awareness that oral hygiene and oral health education has now taken a forefront position in overall health care. The evidence is present for improvement of orthopedic surgery outcomes, the improvement of low birth weight babies survival rates, diabetes control and treatment, and heart disease progression. The individual dental hygienist must be secure, not only in clinical skills, but, also.in basic sciences knowledge, dental sciences knowledge, and patient interaction skills. With these types of skills becoming a greater demand, more emphasis is needed for the development of those skills within the dental hygiene curriculum The addition of those types of expansion skills are requiring a dedication of additional education hours to assure competency in each of those areas. To meet the demand, many 2-year dental hygiene programs throughout the US are expanding their curriculum to meet this need.

The rationale is that the results will help potential dental hygiene students in the selection

of the best program for their needs. Currently, there is limited research concerning the views and perceptions of dentists in the state of West Virginia in regards to their preferences of the education level they desire their dental hygienists to possess. 


\section{STATEMENT OF THE PROBLEM}

Potential dental hygiene students have an option of which entry-level degree they would like to pursue. Of the two degrees, it is unknown which of the two future West Virginia employers would prefer.

The state of West Virginia currently has one four year dental hygiene program, one two plus two year program and one two year program. Four year dental hygiene programs are harder to enroll in due to these programs being very limited. With ADHA recommendations, what would be the future for these educational programs in West Virginia and would the access to the educational opportunities be effected through the loss of economic impact and availability. 


\section{HYPOTHESIS(ES)}

There is no difference in opinions of West Virginia dentists in preference for 2-year or 4year dental hygienists for entry level positions between 2016-2017 and 2018-2019.

There is no difference in preference of West Virginia dentists for 2-year or 4-year dental hygienists for entry level positions.

There is no difference in financial remuneration for entry level dental hygienists between dental hygienists who graduate from a two versus four year program.

There is no difference in skills between dental hygienists who graduate from two verses for year programs.

There is no difference in knowledge between dental hygienists who graduate from two verses for year programs. 


\section{SIGNIFICANCE}

Today, there is a movement in place for the desire to advance the entry-level dental hygiene degree from an associate's degree or certificate to a four-year bachelor degree. It is necessary to conduct this study for aspiring dental hygiene students who are considering a career in the dental world as a dental hygienist. Without any current data on the difference in the characteristics of the individuals possessing the different types of dental hygiene degrees, the perception of employers is unknown. This creates a question as to which of the different entrylevel degrees is held more valuable to possess.

The results of this study will assist aspiring dental hygiene students in determining which entry level degree to pursue for their desired career path. For dental hygienists that desire to have a career in a clinical setting, an associate's degree might be the educational path they choose to pursue. However, for the individuals who desire to teach in higher education as a dental hygienist, they may choose to possess a four-year bachelor's degree that would permit them to teach dental hygiene at a two-year dental hygiene program. Two-year programs have the advantage over some four-year programs in that the student has acceptance to the program upon matriculation; whereas, some 4-year programs do not provide acceptance until the student has completed 2 years of college course not related to dental hygiene. Since acceptance is not guaranteed in some of the 4-year programs, potential students may have pursued a profession to which he or she is denied and have expended a considerable amount of money in that pursuit.

The importance of comparing the original 2016/2017 data to the $2018 / 2019$ data is that it shows the consistency in the dentist's perceptions that are responding to the survey. As the dental 
field changes and has new ways to reach more individuals it is important to keep up to date on new and advancing education. As the populations change it is important to discover ways to bridge access to care, new ways to help individuals and the advancement of the dental hygiene profession. In order to better understand these things, it is important to first and foremost understand the perceptions of dental employers. 


\section{METHODS AND MATERIALS}

Using WVU Research Electronic Data Capture software (RedCap), an online survey consisting of 17 questions was distributed via email to 1,020 dentists throughout the state of West Virginia. The research study was focused on offices that would employ a dental hygienist such as general dentists, orthodontists, pediatric dentists and periodontists that are actively licensed in the state of West Virginia. The online survey was available for three weeks, and in the second week a follow up email was sent as a reminder to complete the survey. This survey was reviewed, renewed and approved by the West Virginia University Institutional Review Board (IRB). IBM SPSS Statistics version 26 was used for statistical analysis. 


\section{RESULTS}

Table 1 Sample Characteristic

\begin{tabular}{lllll}
\hline & $2016-2017$ & $2018-2019$ & \\
& Number & $\%$ & Number & $\%$ \\
Sex & & & & \\
$\quad$ Male & 53 & $67 \%$ & 60 & $71 \%$ \\
Female & 26 & $33 \%$ & 24 & $28 \%$ \\
& & & & \\
Years in Practice & 21 & $27 \%$ & 10 & $12 \%$ \\
$0-10$ years & 18 & $23 \%$ & 17 & $20 \%$ \\
$11-20$ years & 39 & $50 \%$ & 57 & $68 \%$ \\
21 years and above & & & & \\
\hline
\end{tabular}

The 2016/2017 and 2018/2019 survey had a 16\% response rate. As shown in Table 1, the majority of 2016/2017 and 2018/2019 respondents were male and have practiced dentistry for more than 21 years. The survey used a Likert scale for respondents to strongly agree, agree, neutral, disagree and strongly agree with the statements in Table 2 . The majority of dentists were neutral on hiring a 2-year versus a 4-year graduate. Respondents were unlikely to pay a 4-year graduate more than a 2-year graduate. After two years of experience it was reported most that knowledge and clinical efficiency cease to be distinguishing factors when comparing the two degrees. 
Table 2. Survey statements and Responses

\begin{tabular}{lll}
\hline Number & Strongly & Agree Neutral Disagree \\
165 & Strongly \\
& Agree & Disagree \\
\hline
\end{tabular}

I would prefer to hire a recent graduate from a four year dental hygiene program over a recent graduate $\begin{array}{lllll}32 & 33 & 66 & 20 & 14\end{array}$ from a two year dental hygiene program.

I am willing to pay a recent graduate from a four year program in dental hygiene more than a recent graduate from a two year program.

After 2 years of experience, clinical efficiency and $\begin{array}{lllll}22 & 53 & 40 & 44 & 3\end{array}$ knowledge about dentistry cease to be distinguishing factors when comparing a dental hygienist with a four year degree versus one with a two year degree.

$\begin{array}{lllll}17 & 39 & 38 & 44 & 27\end{array}$

Recent 4-year and recent 2-year graduates were considered equal in productivity, clinical skills and patient interaction skills. Recent 4-year graduates were considered to be more knowledgeable in basic science and dental science (Table 3).

Table 3. Survey statements and Responses

\begin{tabular}{lccc}
\hline $\begin{array}{l}\text { Number } \\
165\end{array}$ & 2-year & 4-year Equal \\
\hline $\begin{array}{l}\text { A graduate from which type of dental hygiene } \\
\text { education program is the most productive? }\end{array}$ & 10 & 38 & 111 \\
$\begin{array}{l}\text { Basic Science Knowledge } \\
\text { Dental Science Knowledge }\end{array}$ & 2 & 111 & 51 \\
Patient Interaction Skills & 3 & 102 & 60 \\
Clinical Skills & 8 & 30 & 123 \\
& 7 & 58 & 97
\end{tabular}




\section{Chart 1}

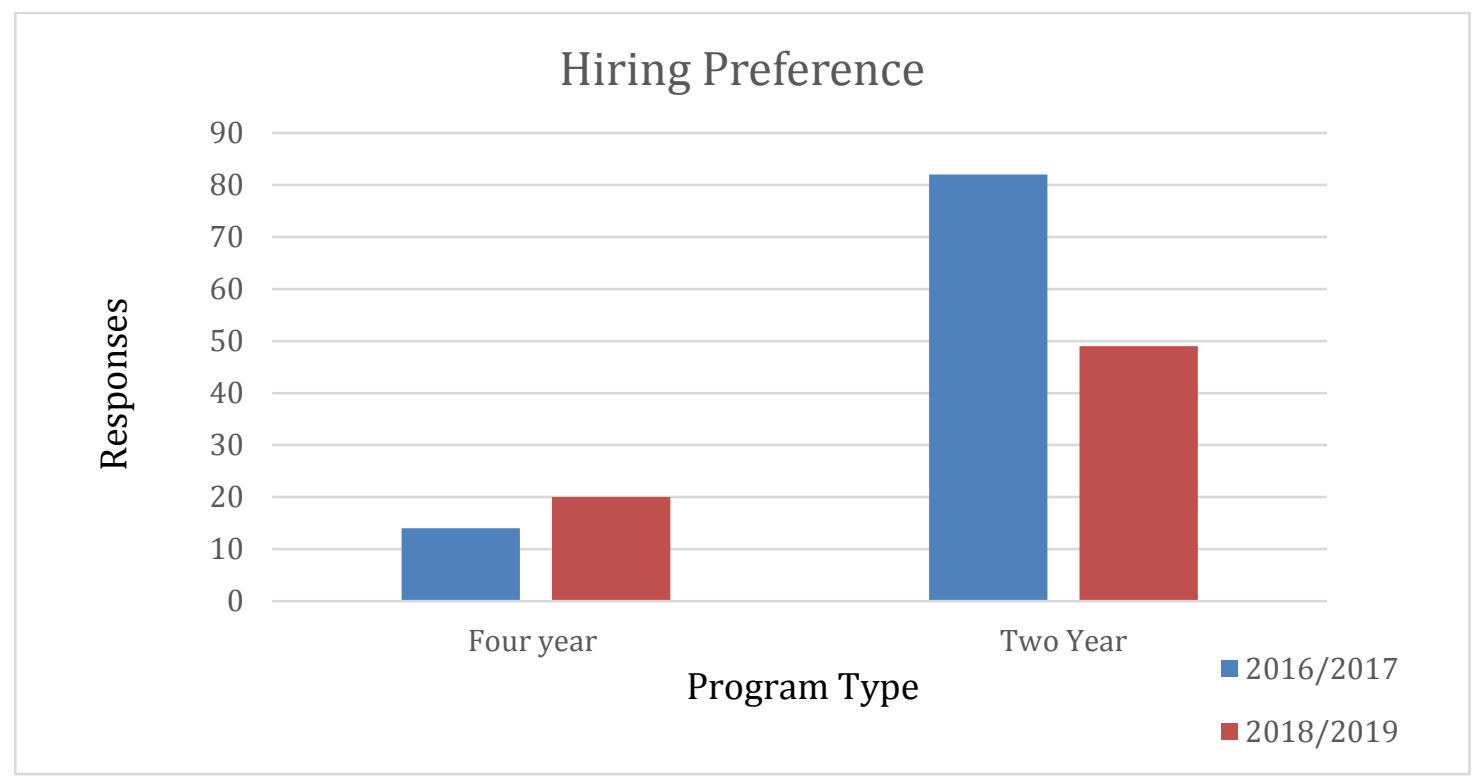

Chart 1: The differences in hiring preference from 2016/2017 and 2018/2019

Over time the hiring preference between the two degrees has changed as reflected in chart 1. Table 4 shows the differences between the two sets of data. Between 2016-2017 and 2018-2019, there was a statistical difference in trend of dentist's preference to hire 4-year over 2year graduates (Chi Square, 5.090, $\mathrm{p}=.032$ ); however additional pay or the perception of greater knowledge relating to 4-year graduates vs. 2-year graduates failed to reach significance (Chi Square, 0.174, p=.750; Chi Square, 0.368, p=.601, respectively). 
Table 4

Bivariate analysis by year of survey, $\mathrm{N}=165$

\begin{tabular}{|c|c|c|c|c|}
\hline & $\begin{array}{l}\text { 2016-2017 } \\
\text { Responses }\end{array}$ & $\begin{array}{l}\text { 2018-2019 } \\
\text { Responses }\end{array}$ & Chi-square & $P$-value \\
\hline \multicolumn{3}{|c|}{ I would prefer to hire a recent } & 5.090 & .032 \\
\hline \multicolumn{5}{|c|}{ Graduate from a 4-year program } \\
\hline \multicolumn{5}{|c|}{ Rather than a 2-year program 1} \\
\hline Yes & 14 & 20 & & \\
\hline No & 82 & 49 & & \\
\hline $\begin{array}{l}\text { I am v } \\
\text { gradu } \\
\text { progr }\end{array}$ & & & & \\
\hline \multicolumn{2}{|c|}{$\begin{array}{l}\text { program more than a recent } \\
\text { graduate from a } 2 \text {-year program }\end{array}$} & & .174 & .750 \\
\hline Yes & 40 & 31 & & \\
\hline No & 56 & 38 & & \\
\hline \multicolumn{5}{|c|}{$\begin{array}{l}\text { After } 2 \text { years of experience, } \\
\text { clinical efficiency and knowledge } \\
\text { about dentistry cease to be } \\
\text { distinguishing factors when } \\
\text { comparing a } 4 \text {-year degree versus }\end{array}$} \\
\hline a 2-yc & & & .368 & .601 \\
\hline Yes & 29 & 18 & & \\
\hline No & 65 & 50 & & \\
\hline \multicolumn{5}{|c|}{$\begin{array}{l}\text { Please select the recent dental } \\
\text { hygiene graduate who you } \\
\text { perceive to be the strongest in } \\
\text { these specific areas. }\end{array}$} \\
\hline Profes & & & $*$ & $*$ \\
\hline Yes & 92 & 67 & & \\
\hline No & 0 & 0 & & \\
\hline \multicolumn{3}{|c|}{ Basic Science knowledge ${ }^{2}$} & $*$ & $*$ \\
\hline Yes & 96 & 68 & & \\
\hline No & 0 & 0 & & \\
\hline \multicolumn{3}{|c|}{ Dental Science knowledge ${ }^{2}$} & $*$ & $*$ \\
\hline Yes & 96 & 68 & & \\
\hline No & 0 & 0 & & \\
\hline
\end{tabular}


Patient Interaction Skills ${ }^{2}$

Yes

No

Clinical Skills ${ }^{2}$

Yes

No
95

0
$*$

68

0
*

$*$

958

0

${ }^{1}$ Definitions: Yes= Likert responses "agree" or "strongly agree"; No= Likert response "disagree," "strongly disagree" or "neutral."

${ }^{2}$ All participant responses were "agree" or "strongly agree" that the graduates of both programs had these characteristics, *therefore no statistics are computed.

Missing responses occurred in some categories and are not listed here. 


\section{DISCUSSION}

Although there is no preference of West Virginia dentists for hiring a 2-year or 4- year dental hygiene graduate, over time there was a time trend to prefer hiring 4-year dental hygiene graduates. Between the 2016/2017 and 2018/2019 data sets, professionalism, basic science knowledge, dental knowledge, patient interaction and clinical skills failed to meet a statistical difference.

For aspiring dental hygienists who are solely considering financial aspects of the two degrees, it is likely more suitable to complete a 2-year program while it is still available. For individuals who are considering careers such as those in academia, cooperate for public health sectors a 4-year program is necessary. Although it is considered desirable to possess a 4-year degree it is not necessary at this time to acquire the 4-year degree.

Previously there has been a movement to advance the dental hygiene entry-level degree from a two-year dental hygiene degree to a four-year dental hygiene degree. As the dental hygiene profession evolves, there is a desire to advance the entry-level to a bachelor's degree with the idea that it would better prepare dental hygienists for the new evolving roles in our healthcare system. The ADHA has had this current policy for 43 years, however in the coming years, there is an effort to make changes on the existing policy.

New roles and opportunities have started to be introduced into the dental hygiene profession. To take advantages of these opportunities, the members of the ADHA are prepared for their new roles and possibilities in the dental hygiene field (11). Future dental hygienists will need to adapt to the new advancements. 
The Strategic plan for dental hygiene education consists of three goals: education, alliances and advocacy. The Academy for Academic Leadership and the leaders at the ADHA worked together to expedite a pilot program that consisted of seven schools: Vermont Technical College, Miami Dade College, University Detroit Mercy, University of Missouri-Kansas City, University of New Mexico, Eastern Washington University and Idaho State University. Each of these dental hygiene programs has their own specific education curriculum and domains to reflect key commonalities of the new dental hygiene education. Phase two of the pilot education project launched in the fall of 2015. The leaders at the ADHA are still working with the interested dental hygiene programs to adapt the curriculum to educate dental hygiene students with the continuously changing population. New partnerships and alliances have been developing in new organizations that are created to improve the public's overall health and oral health. The leaders of the ADHA have become alliances with the Alliance for Radiation Safety in Pediatric Imaging, Alliance's Image Gently campaign and the Oral Cancer Foundation. The ADHA Strategic Plan calls for representation nationally. They had met with the Association of Public Health Dentistry and the Association of State and Territorial Dental Directors and hoped to have a partnership with both eventually. The ADHA is targeting the states that have active legislations that are supportive of their cause (11). The ADHA's Strategic Plan of the three goals will lead to the advancement of the dental hygiene curriculum to accommodate the new advancement of the dental hygiene profession. 


\section{CONCLUSIONS}

There was a statistical difference between 2016-2017 and 2018-2019 preferences with a trend to preferring hiring a 4-year dental hygiene graduate in 2018-2019 in West Virginia. There was no difference in preferring to pay more for either degree. Perception of greater knowledge in comparison of the two degrees failed to reach significance.

For the individuals who chose to complete the higher degree have more career opportunities such as school sealant programs, teaching higher education, corporate and government sector jobs. For individuals who want to work in private practice settings they may choose to complete a two year education program. Dependent upon the individual the choice lies within the type of career they wish to have in dental hygiene. 


\section{RECOMMENDATIONS FOR FUTURE STUDIES}

To better this study it is necessary to understand why aspiring dental hygiene students chose one degree path over another. With that, there are many aspects that could be affected by the ADHA supporting the entry level degree progressing to the four year degree.

The following recommendations are based off the results of this study:

- Expand survey on a national level

- Indicate how dental practices could be affected by advancing the dental hygiene degree

- Challenge how advancing the dental hygiene degree could affect access to care

- Investigate financial return of a two versus four year dental hygiene degree

- Evaluate financial return to the practice if one degree is better equipped to benefit the practice

- Identify what influences dental hygienists to choose one academic approach over the other

To allow dental hygiene education to evolve to continue to meet the needs of patients, a study needs to be completed to determine the changing oral health needs of patients in, as well as, out of the traditional clinical setting in order for the profession to continue to grow and serve all equally and completely. 


\section{REFERENCES}

1. [Internet]. College Stats; [2013 May 15]. Available from:

https://collegestats.org/2013/05/the-happy-state-of-college-graduates/

2. [Internet]. ADHA; 2016 Oct 18. Available from: http://www.adha.org/resourcesdocs/7525_Map_of_DH_Programs_Per_State.pdf.

3. Portillo KM, Calley KH. A Survey of Degree Completion Programs in Dental Hygiene Education. J Dent Educ. 2012 Jul 10; 77(5):554-63.

4. Darby ML. Mosby's Comprehensive Review of Dental Hygiene. $7^{\text {th }}$ ed. Linda Duncan; 2012.

5. Rogers C, Johnson TB, Gurenlian JAR. New York State Dental Hygienists' Perceptions of a Baccalaureate Degree as the Entry-Level Degree Required for Practice. J Dent Hyg. 2015 Jun; 89(2):13-21.

6. Kanji Z, Sunell S, Boschma G, Imai P, Craig BJ. Outcomes of Dental Hygiene Baccalaureate Degree Education in Canada. J Dent Educ. 2010 Oct 5; 75(3):310-20.

7. Stolberg RL, Tilliss T. THE BACCALAUREATE-EDUCATED DENTAL HYGIENIST. J Evid Based Dent Pract. 2016 Nov 10; 16:136-43.

8. Sparer, M. Medicaid managed care: Costs, access, and quality of care. POLICY; 2012 Sep. 36 p. Report No.:23

9. Nasseh K, Vujicic M, Yarbrough C. A ten-year, state-by-state, analysis of Medicaid feefor-service reimbursement rates for dental care services. Chicago, Illinois: American Dental Association's Health Policy Institute; 2014 Oct 16; 16 p. 
10. Nasseh K, Vujicic M, Wall T. Most Important Barriers to Dental Care Are Financial, Not Supply Related. Chicago, Illinois: American Dental Association's Health Policy Institute: 2014 Oct 9; 9p.

11. Boyleston ES, Collins MA. Critical Issues in Dental Hygiene. J Dent Hyg. 2012; 86(3):168-78.

12. [Internet]. ADHA; 2014 [2017 Nov 21]. Available from: https://www.adha.org/resourcesdocs/2014-2015_ADHA_Annual_Report.pdf.

13. [Internet]. ADHA; 2020 [2019 June]. Available from: https://www.adha.org/resourcesdocs/7614_Policy_Manual.pdf 


\section{Appendix A}

Table 1: The majority of 2016/2017 and 2019/2020 respondents were male and have practiced dentistry for more than 21 years.

\section{Table 1 Sample Characteristic}

\begin{tabular}{|c|c|c|c|c|}
\hline & \multicolumn{2}{|c|}{ 2016-2017 } & \multicolumn{2}{|c|}{ 2018-2019 } \\
\hline & Number & $\%$ & Number & $\%$ \\
\hline \multicolumn{5}{|l|}{ Sex } \\
\hline Male & 53 & $67 \%$ & 60 & $71 \%$ \\
\hline Female & 26 & $33 \%$ & 24 & $28 \%$ \\
\hline \multicolumn{5}{|l|}{ Years in Practice } \\
\hline $0-10$ years & 21 & $27 \%$ & 10 & $12 \%$ \\
\hline $11-20$ years & 18 & $23 \%$ & 17 & $20 \%$ \\
\hline 21 years and above & 39 & $50 \%$ & 57 & $68 \%$ \\
\hline
\end{tabular}




\section{Appendix B}

Table 2. Survey statements and Responses

Number

165

I would prefer to hire a recent graduate from a four year dental hygiene program over a recent graduate from a two year dental hygiene program.

I am willing to pay a recent graduate from a four year program in dental hygiene more than a recent graduate from a two year program.

After 2 years of experience, clinical efficiency and knowledge about dentistry cease to be distinguishing factors when comparing a dental hygienist with a four year degree versus one with a two year degree.
Strongly Agree Neutral Disagree Strongly Agree Disagree

$\begin{array}{lllll}32 & 33 & 66 & 20 & 14\end{array}$

$\begin{array}{lllll}17 & 39 & 38 & 44 & 27\end{array}$

$\begin{array}{lllll}22 & 53 & 40 & 44 & 3\end{array}$




\section{Appendix C}

Table 3. Survey statements and Responses

\begin{tabular}{llll}
\hline $\begin{array}{l}\text { Number } \\
165\end{array}$ & 2-year & 4-year Equal \\
\hline $\begin{array}{l}\text { A graduate from which type of dental hygiene } \\
\text { education program is the most productive? }\end{array}$ & 10 & 38 & 111 \\
$\begin{array}{l}\text { Basic Science Knowledge } \\
\text { Dental Science Knowledge }\end{array}$ & 2 & 111 & 51 \\
Patient Interaction Skills & 3 & 102 & 60 \\
Clinical Skills & 8 & 30 & 123
\end{tabular}




\section{Appendix D}

\section{Chart 1}

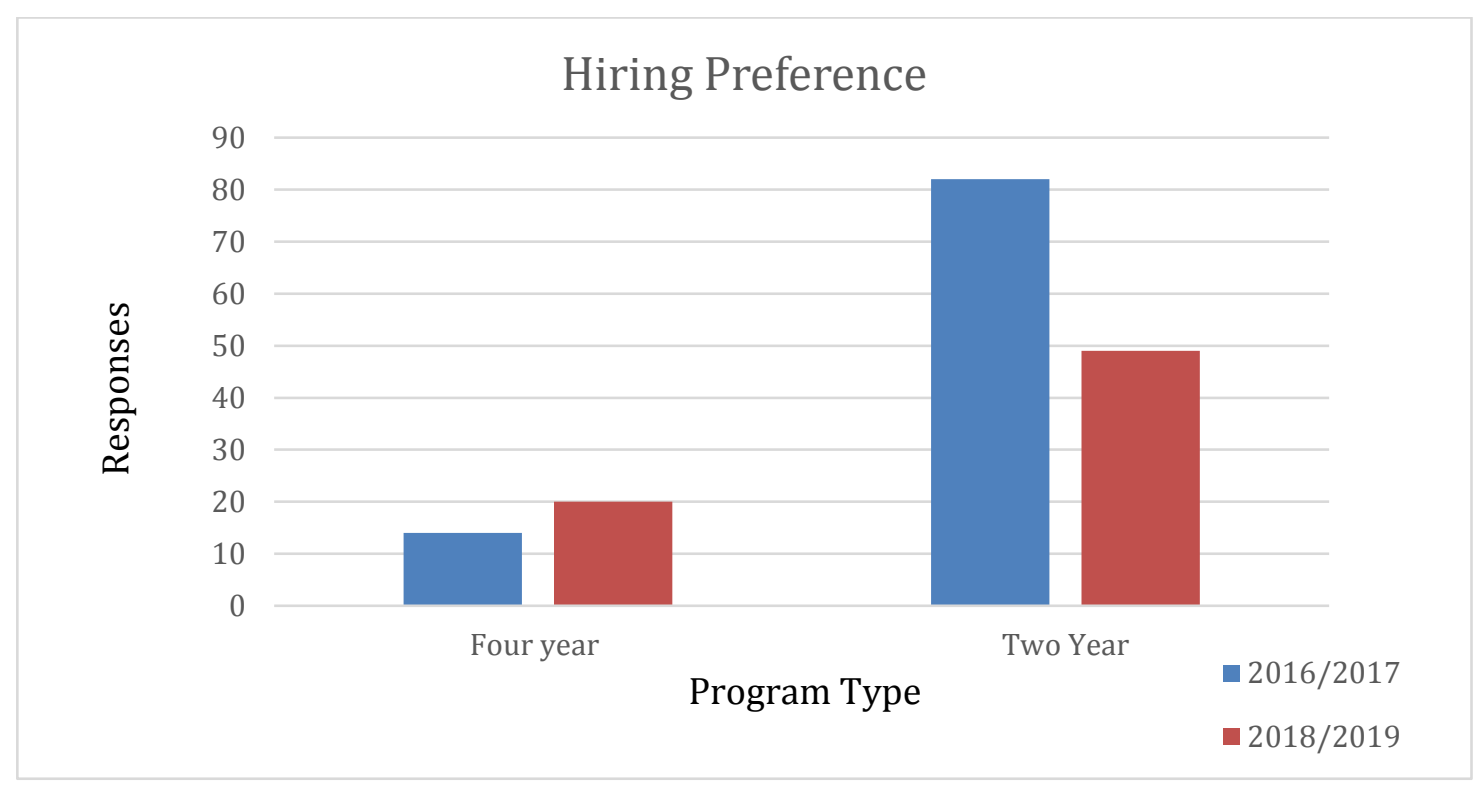

Chart 1: The differences in hiring preference from 2016/2017 and 2018/2019 
Appendix E

Table 4

Bivariate analysis by year of survey, $\mathrm{N}=165$

\begin{tabular}{lccc}
\hline- & & & \\
value & & & \\
& & & \\
& Responses & Responses & \\
\end{tabular}

I would prefer to hire a recent

$$
.032
$$

Graduate from a 4-year program

Rather than a 2-year program ${ }^{1}$

Yes 14

No 82

I am willing to pay a recent graduate from a 4-year program more than a recent graduate from a 2-year program Yes 40

No 56

31

After 2 years of experience, clinical efficiency and knowledge about dentistry cease to be distinguishing factors when comparing a 4-year degree versus

$\begin{array}{lll}\text { a 2-year degree } & & \\ \text { Yes } & 29 & 18 \\ \text { No } & 65 & 50\end{array}$

Please select the recent dental hygiene graduate who you perceive to be the strongest in these specific areas. Professionalism $^{2}$

Yes

No
92

0
67 
Basic science knowledge ${ }^{2}$

Yes

No

\section{Dental knowledge ${ }^{2}$}

Yes

No
96

0

68

0
*

$*$
Patient Interaction Skills ${ }^{2}$

Yes

No

\section{Clinical Skills ${ }^{2}$}

Yes

No
96

0
*

68

0

$*$

$*$

68

0

$0 \quad 0$

95

68

0 0

${ }^{1}$ Definitions: Yes= Likert responses "agree" or "strongly agree"; No= Likert response "disagree," "strongly disagree" or "neutral."

${ }^{2}$ All participant responses were "agree" or "strongly agree" that the graduates of both programs had these characteristics, *therefore no statistics are computed.

Missing responses occurred in some categories and are not listed here. 


\section{Appendix F}

Please complete the following survey under the knowledge that we consider a recent graduate as someone who is within 2 years post-graduation.

1. Do you currently work in a private practice setting more than once a week?
A) Yes
B) No

2. You would prefer to hire a recent graduate from a 4 year dental hygiene program over a recent graduate from a 2 year dental hygiene program.
A) Strongly agree
B) Agree
C) Neutral
D) Disagree
E) Strongly disagree

3. You are willing to pay a recent graduate from a 4 year program in dental hygiene more than a recent graduate from a 2 year program.
A) Strongly agree
B) Agree
C) Neutral
D) Disagree
E) Strongly disagree

4. After 2 years of experience, clinical efficiency and knowledge about dentistry cease to be distinguishing factors when comparing a dental hygienist with a 2 year degree versus one with a 4 year degree.
A) Strongly agree
B) Agree
C) Neutral
D) Disagree
E) Strongly disagree

5. If you are neutral or disagree on previous question, which level of education do you prefer?
a) Recent 4 year graduate
B) Neutral
C) Recent 2 year graduate

6. 4 year dental hygiene graduates are more productive than 2 year dental hygiene graduates
A) Strongly agree
B) Agree
C) Neutral
D) Disagree
E) Strongly disagree

7. Please select the recent dental hygiene graduate who you perceive to be the strongest in these specific areas.

1. Basic sciences
a) Recent 4 year graduate
b) Recent 2 year graduate
c) Recent $2 \& 4$ year graduates are equally strong

2. Dental sciences
a) Recent 4 year graduate
b) Recent 2 year graduate
c) Recent $2 \& 4$ year graduates are equally strong

3. Patient interaction
a) Recent 4 year graduate
b) Recent 2 year graduate
c) Recent $2 \& 4$ year graduates are equally strong

4. Clinical skills
a) Recent 4 year graduate
b) Recent 2 year graduate
c) Recent $2 \& 4$ year graduates are equally strong

1. What is your gender?
A) Female
B) Male
C) Transgender/transitioning

2. What is your age?
A) 20-29 years old
B) 30-39 years old
C) 40-49 years old
D) $50-59$
E) $60+$ 
3. Amount of years practicing dentistry?
A) 0-5 years
B) 6-10 years
C) $11-20$ years $D) \geq 21$ years

4. What type of practice are you currently under?
A) Pediatrics B) Periodontics
C) General
D) Orthodontics

5. I prefer to hire.....
A) Recent 4 year graduate
B) Neutral
C) Recent 2 year graduate

6. Did your dental school have a dental hygiene program?
A) Yes
B) Don't Know
C) No

7. If yes to the previous question, how long was the dental hygiene program at your dental school?
A) 2 years
B) 4 years
C) Unsure

8. Did you graduate from a US dental school?
A) Yes
B) No 
VITA

\section{Kaitlyn M. McQuain}

2020

Kaitlynmcory@aol.com

Education:

Master of Science, Dental Hygiene, West Virginia University, August 2020

Thesis: West Virginia Dentists' Perception of the Knowledge and Skills of Two vs. Four Year Dental Hygiene Graduates

Advisor: Dr. Alcinda K TRickett Shockey, DHSc, MA, BS, RDH

Bachelor of Science, Dental Hygiene, West Virginia University, May 2018

\section{Licensure and Certifications}

Cardiopulmonary Resuscitation Certification, American Heart Association. (October 2016- Present)

West Virginia In-Office Bleaching Permit, West Virginia Board of Dental Examiners. (May 2018-Present)

West Virginia Dental Hygiene License, West Virginia Board of Dental examiners. (June 2019- Present)

Pennsylvania Local Anesthesia for Dental Hygienists' Certificate, Pennsylvania Board of Dental Examiners. (June 2018- Present) 
Pennsylvania Dental Hygiene License, Pennsylvania Board of Dental examiners. (June 2018-Present)

\section{Employment}

Clinical Hygiene:

Dental Hygienist: DentalWorks, June 2018- Present

Teaching Experience:

Teaching Assistant, West Virginia University, School of Dentistry, Department of Dental Hygiene, Part-time August 2019-December 2019

Provided clinical instruction/evaluation for $3^{\text {rd }}$ and $4^{\text {th }}$ year dental hygiene students. Provided assistance with $3^{\text {rd }}$ year public health course.

\section{Public Service}

Volunteer, Student American Dental Hygienists' Association Homecoming Parade, Morgantown, West Virginia. (October 9, 2015)

Volunteer, Student American Dental Hygienists' Association Trunk-or-Treat, Morgantown, West Virginia. (October 27, 2015)

Volunteer, Golden Living Center, Morgantown, West Virginia. (September 3, 2016)

Volunteer, Golden Living Center, Morgantown, West Virginia. (September 23, 2016)

Volunteer, Ronald McDonald House, Morgantown, West Virginia. (October 6, 2016)

Volunteer, Student American Dental Hygienists' Association Trunk-or-Treat, Morgantown, West Virginia. (October 19, 2016) 
Volunteer, Rosenbaum House, Morgantown, West Virginia. (January 7, 2017)

Volunteer, Relay For Life, American Cancer Association, Morgantown, West Virginia. (April 25, 2017)

Volunteer, Crichton Elementary School, Quinwood, West Virginia. (May 19, 2017)

Volunteer, Golden Living Center, Morgantown, West Virginia. (May 26, 2017)

Volunteer, Western Greenbrier Middle School, Crawley, West Virginia. (June 9, 2017)

Volunteer, Dr. Gene Ray Carr INC, Open house, Rainelle, West Virginia. (June 9, 2017) 


\section{Dedications}

Committee members:

Dr. Alcinda Trickett Shockey, thank you for being the committee chair and always offering your wisdom and guidance. Throughout my entire undergraduate and graduate career you've been a great source of information and confidence. I appreciate your kindness and willingness to help.

Dr. R Constance Wiener, thank you for your endless knowledge throughout this thesis. You always offered your wisdom, help and time generously. I appreciate you greatly.

Ms. Ashlee B Sowards, thank you for being a part of this project not only during my journey as a graduate student but also as an undergraduate student. You have given knowledge, advice and a listening ear. I am very grateful to have you as a part of education journey and this research study.

Ms. Amy Funk and Ms. Lori Groover, thank you for all the guidance you both have given me throughout my time at West Virginia University. You have helped me countless times and for that I am so grateful.

Family:

Cameron McQuain, my husband, thank you for supporting my education journey and always giving me your love and support with all my endeavors.

Tamara and Ed Cory, my parents, thank you for loving me and supporting my dreams always. Without you I wouldn't be where I am today.

Friends: 
Isabella McDaniel, my friend, thank you for embarking on this journey with me. It has been wonderful to be able to go through not only undergrad with you but this graduate program. I am beyond thankful to have had you there to lend a helping hand or a listening ear. I am grateful to call you friend. 